\title{
Analysis on Expansion of Goodlife Fitness into China
}

\author{
Yuan Zhai ${ }^{1, *}$ \\ ${ }^{1}$ University of Toronto, 27 King's College Cir, Toronto, ON M5S, Canada \\ *Corresponding author.Email: yuan_zhai@hotmail.com
}

\begin{abstract}
For the past few decades, China, with its huge population base and fast-growing economy, has attracted many international investors and businesses from different industries. As the new generation's consumption ideology progresses, the Chinese people are becoming more aware of personal health, quality of life and physical appearance. With the domestic fitness industry still scattered and under-developed, there provides an opportunity for Goodlife Fitness to expand into the Chinese market. The purpose of this article is to study the possibility of entering the Chinese fitness market by using SWOT analysis, Porter's Five Forces analysis, and other relevant analysis. The results show that the Chinese fitness market is going into a more matured stage which provides opportunities for companies to enter.
\end{abstract}

Keywords: MAU, Monthly active users, Goodlife Fitness, Fitness industry.

\section{INTRODUCTION}

The Chinese fitness industry has gone through three main stages, infancy stage of 2000-2004, consolidation period after 2010 , and recovery phase after 2015 [1]. As the world is struck by the Corona Virus in 2020, the domestic fitness industry is experiencing another transformation period which provides opportunities for company like Goodlife Fitness, with years of experience in health and fitness sector, to enter. Although timing might be right, there are also potential risks such as lack of market transparency, strong regional and online competitors, weak customer cognition, and changing government policies. Moreover, Goodlife Fitness has little experience operating outside of Canada, and its current offline-heavy business model might be hard to survive in the Chinese market. Through this paper, a detailed analysis on company, industry, and factors regarding business entry will be conducted to study the possibility of success in the new market, and suggestions will be provided to management team for decision making. In general, the author hopes that this paper will help the management team and whoever is reading to enhance its understanding and horizon of the Chinese fitness market and produce the best decision for the benefit of the company.

\section{ANALYSIS}

\subsection{Company Analysis}

Goodlife Fitness, founded in 1979 by PatchellEvans, is the largest fitness chain in Canada and the fourth largest in the world, with over 1.25 million customers, and counting [2]. This amounts to one in every twenty-eight Canadians being Goodlife Fitness members. After it headquartered and opened its first fitness in London, it has established more than 365 clubs across Canada, with over 3,000 corporate partners, and close to 15,000 associates working full-time or part-time [3].

Over the years, it has played a pivotal role in transforming the health and wellness of Canadians every day. Besides the usual gym facilities, the company offers group fitness classes, like athletic, strength training, aqua, cardio, dance, cycling, yoga and hot yoga classes, along with group and personal training programs. According to Mo Hagan, Goodlife's VP of Operations, the company does not believe in segmenting the market by creating the 'wow' factor through charging extravagant membership fees to customers like some of its competitors, reaffirming the company's commitment to providing affordability for its users. 
At Goodlife Fitness, the goal of the corporation is to give every Canadian the opportunity to live a fit and healthy good life. It encourages women and kids to get active by opening "For Women" club in 1983 and creating Goodlife Kids Foundation in 1998. The magazine "Living the Good Life" was published in 2000 and it surpassed 1 million copies. Goodlife Fitness also concentrates on the development of the entire social well-being and promote corporation social responsibility by establishing the Kilee Patchell-Evans Autism Research Group in 2003 and holding Toronto GoodLife Fitness Marathon each year.

As Goodlife Fitness playing a dominant role across Canada, it has not seized the global market shares. Outside of Canada, it has only established a partnership with US based gym, 24 Hours Fitness, which Goodlife Fitness's members can also use its' facilities. As the Canadian market is almost fully saturated, it is important for the company to consider expand its business and promote the brand internationally with its expert experience in fitness and management strategies.

\subsection{Industry Analysis}

The first fitness club in China was found in Beijing in 1987. From then on, the fitness industry in China grew and has gone in three stages (see "Table 1"):

Table 1. Three stages of fitness industry in China

\begin{tabular}{|c|c|c|}
\hline $\begin{array}{l}\text { 2000-2010 } \\
\text { Infancy Stage }\end{array}$ & $\begin{array}{l}\text { 2011-2015 } \\
\text { Consolidation Stage }\end{array}$ & $\begin{array}{l}\text { 2016-Now } \\
\text { Recovery Stage }\end{array}$ \\
\hline $\begin{array}{l}\text {-The success of Beijing's Olympic } \\
\text { Games bid in } 2001 \text { triggered national } \\
\text { fitness sentiment with few renowned } \\
\text { chain brands, including Hosa, } \\
\text { Nirvana, Will's, and Tera Welness, } \\
\text { emerged with high annual } \\
\text { membership fees of more than } \\
10,000 \text { RMB } \\
\text {-Benefitted from the large population } \\
\text { size, pioneering players quickly grew } \\
\text { while attracted regional players to } \\
\text { target different segments. As } \\
\text { competition intensified, } \\
\text { membership fees were reduced } \\
\text { significantly to around } 3,000 \text { RMB per } \\
\text { year. Since } 2008 \text { 's financial crisis hit } \\
\text { China, fitness demand shrank and } \\
\text { the growth rate slows down. }\end{array}$ & $\begin{array}{l}\text {-As industry saturation is high, the } \\
\text { business model of "crowd selling + } \\
\text { prepayment" and discount fees became } \\
\text { unsustainable for many unprofitable gyms, } \\
\text { leading to a period of consolidation. The } \\
\text { industry also began to explore new } \\
\text { business models to attract customers such } \\
\text { as group classes and smart gyms. }\end{array}$ & $\begin{array}{l}\text {-Started in 2016, the government introduced } \\
\text { several strategic documents encouraging } \\
\text { large companies to be internationally } \\
\text { competitive while medium to small } \\
\text { companies to be specialized. } \\
\text {-The State Council also released the Healthy } \\
\text { China Initiate (2019-2030) to encourage } \\
\text { people to exercise. } \\
\text {-The Chinese fitness industry has } \\
\text { transformed with more model gyms emerged } \\
\text { including smart gyms - Sunpig, } 24 \mathrm{H} \text { fitness } \\
\text { brand - Liking Fit, group exercise brands - } \\
\text { Super Monkey and Spacecycle, sports O2O } \\
\text { - Lefit, specialized chain gyms - Fine Yoga } \\
\text { and Pure Yoga. }\end{array}$ \\
\hline
\end{tabular}

\subsection{Porter's Five Forces Analysis}

\subsubsection{Supplier Power}

The supplier power for the fitness industry facing is medium. The suppliers for fitness industry are mainly constituted by equipment manufacturers, coaches and land property leaser. To begin with, the fitness equipment industry is highly competitive with many equipment manufacturers worldwide, thus, the supplier power for equipment manufacturers is weak. Secondly, more than $60 \%$ of a total number of coaches do not have college or higher degree, and less than $10 \%$ of coaches have more than 5 years of coaching experience [3]. Moreover, the coaching qualification in China is still very chaotic because there is no unified standard, made by the government, for coach qualification. Therefore, the supplier power for experienced and professional coaches is strong. Finally, there are two groups of land property leasers, specifically, one group is for first-tier coastal cities, such as Beijing and Shanghai, and another group is for second-tier cities, like cities in non-coastal provinces [4]. For first-tier cities, the demand for land properties is very high, so the price is non-bargainable and expensive. In contrast, for second-tier cities, there is a surplus in land 
properties supply since government implemented the expansionary fiscal policy in 2008. Therefore, the leaser of first-tier cities has strong supplier power while the leaser of second-tier cities has weak supplier power.

\subsubsection{Buyer Power}

There are two types of buyers, buyers daily go to fitness clubs and buyers go to fitness clubs only in leisure time or weekend [1]. For the first type of buyers, they have weak buyer power because they have to choose fitness clubs that are convenient to reach. In contrast, for the second type of buyer, they only go to fitness club when they have time, thus they are more willing to go to a club rather than more convenient. In China where business operates in densely located areas, buyers have more options to choose from and lower switching cost.

\subsubsection{Competitive Rivalry}

In China, the fitness industry can be separated into two groups, one for coastal cities and another for non-coastal cities. For coastal cities, such as Beijing and Shanghai, competition is fierce as fitness clubs are well established. However, comparing to other top-tier cities with the same level of GDP in the world, the penetration is still relatively low (Figure 1) For instance, Hong Kong has 3.5 times more fitness clubs than Beijing has, 5.6 times more than Shanghai has, and 9 times more than Guangzhou has [4]. For non-coastal cities in Middle and Western China, the number of fitness clubs is relatively small, and the concept of getting exercise using fitness clubs is still novel to many. Therefore, the competition in coastal city is high but still with room to grow while the competition in non-coastal city is relatively weak but citizens lack fitness knowledge and perceptions.

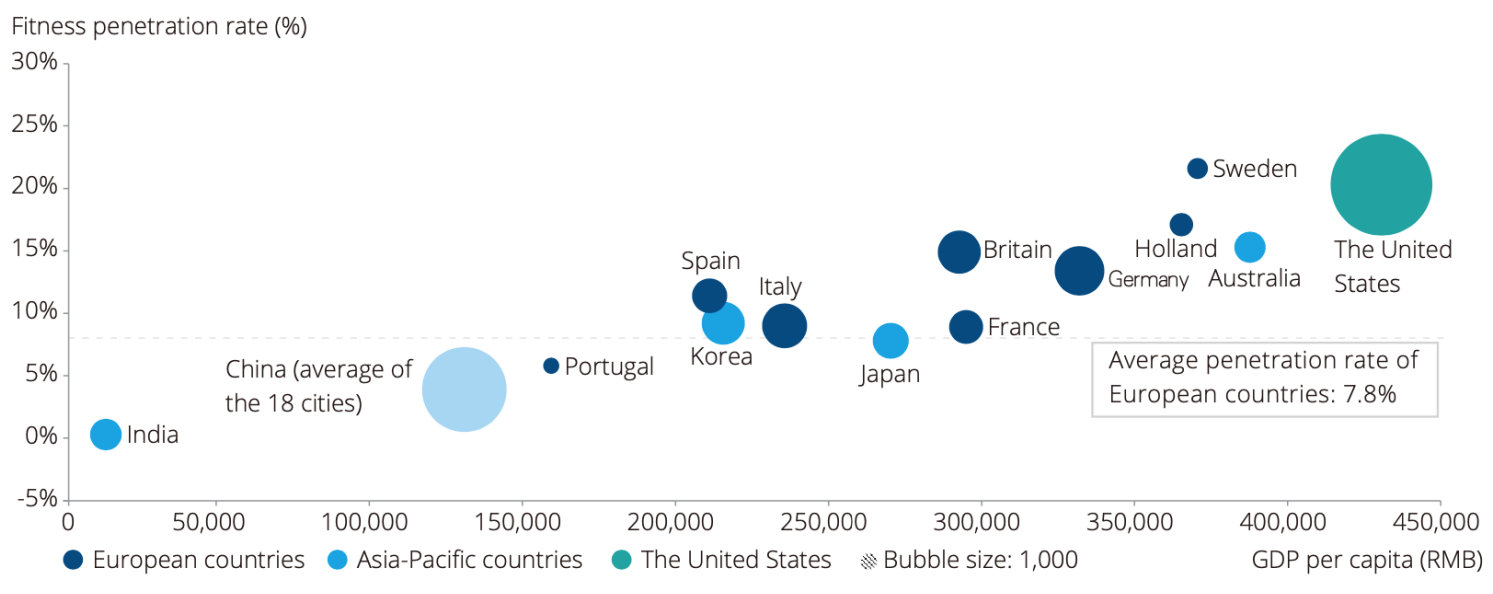

Note: A currency exchange rate of USD:CNY 1:6.8785 (28 December 2018) was used in this graph.

Figure 1 Chinese fitness market vs. the international fitness market, 2019' (Unit: \%, RMB).

\subsubsection{Threat of Substitution}

The major substitution of fitness club is outdoor activities, gym parks and square/park dancing. As air pollution problem in China has been seriously addressed by the Chinese government, more people are willing to exercise outdoor together for free. However, as a small group survey is conducted, we see that younger generation (below 40s) are willing to use gym facilities and professional trainings for physical benefits; However, citizens older than 50s are reluctant to pay for exercise. In this case, it can be concluded that outdoor activities are major threats to the fitness industry but, as people's
Data from Deloitte's China Gym Development White Paper

physical education advances, outdoor activities will eventually become a complement.

The other substitution of fitness club is online fitness follow-along applications such as Keep. Keep, released in 2015, is an app with fitness education and follow-along, nutritional guidance, online social, and sportswear purchase/recommendation features [5]. It has reached 100 million subscribers in 2020 and started to operate offline fitness clubs [6]. Keep has a very successful business model with cheap online courses to attract users and using the online resources to bring consumers to offline clubs where high fees can be charged. 


\subsubsection{Threat of New Entry}

Chinese fitness industry has developed for more than 2 decades, so the industry is comparatively balanced. Many international fitness firms have entered Chinese for many years, and some local fitness firms exit due to poor financials. It is believed that there will be more international brands to enter as the fitness market still has room to grow; However, players enter the market will need to explore their strength and develop efficient models which fit the local appetite.

\subsection{Major Competitor Analysis}

In 2019 , there are about 27,600 gyms in 18 cities with only 1,000 of these gyms managed by

Table 2. Differences of business forms of gyms in China

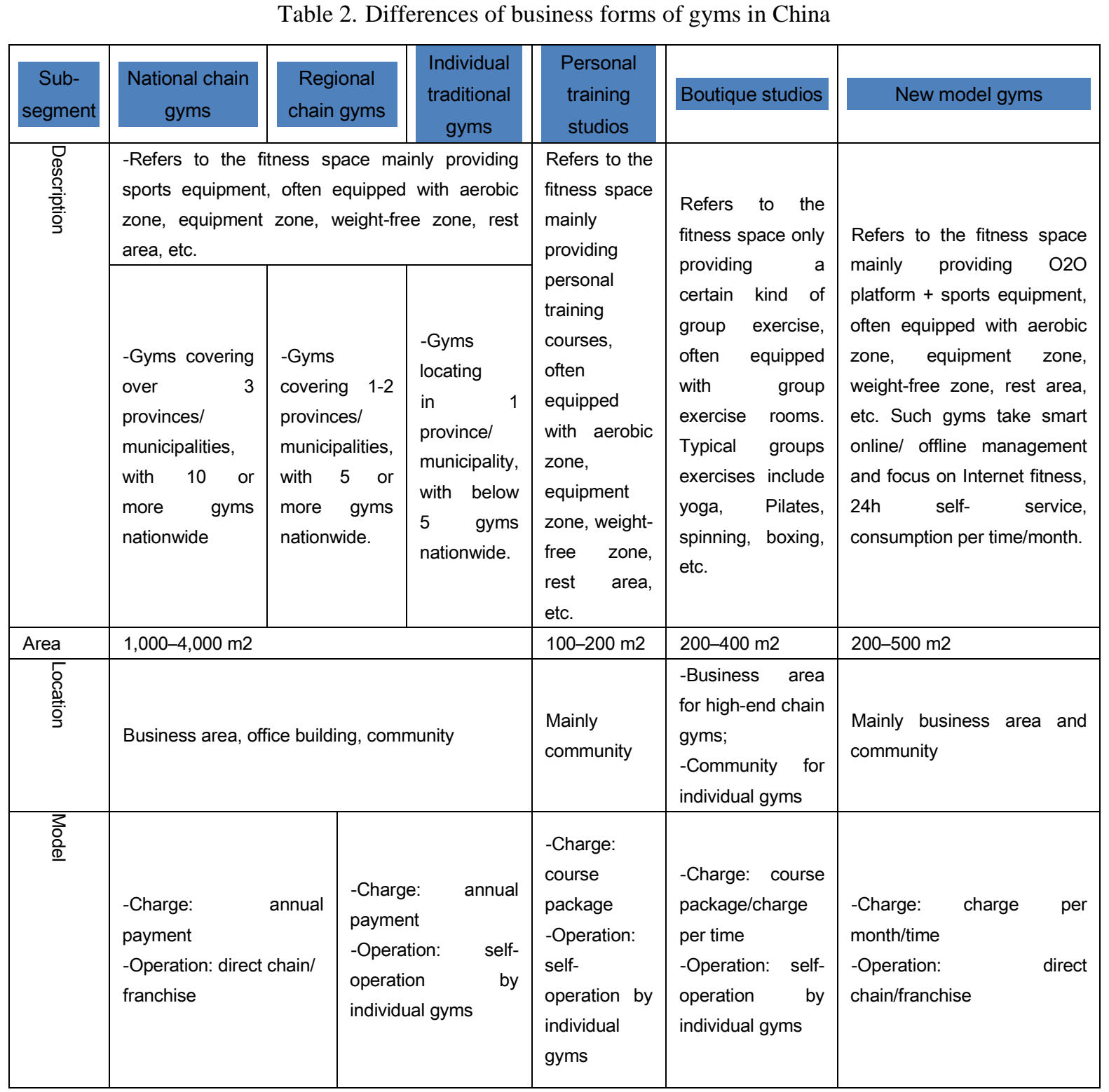

one of the top 10 industry brands (around 3.8\%) [6]. This shows that the industry has a low concentration ratio and has yet to establish a strong leading brand. One reason behind low concentration ratio is that expansion has been limited by high capital investment, high management cost, and low localization capacity. People in different city tiers and areas have dramatically different habit and perception, thus it is hard for company to operate successfully on a national scale. With expansion limited, the market has developed more niches and brands with specialization. The author analyzed different segmentation in detail, as shown in Table 2. 


\begin{tabular}{|c|c|c|c|c|c|c|}
\hline $\begin{array}{c}\text { Sub- } \\
\text { segment }\end{array}$ & \multicolumn{3}{|c|}{ National chain gyms } & $\begin{array}{l}\text { Regional } \\
\text { chain gyms }\end{array}$ & $\begin{array}{l}\text { Individual } \\
\text { traditional gyms }\end{array}$ & Personal training studios \\
\hline 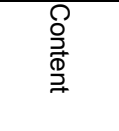 & $\begin{array}{l}\text { Equipment/Group } \\
\text { training/Service }\end{array}$ & Ex & cise/Personal & $\begin{array}{l}\text { Personal } \\
\text { Training/Little } \\
\text { Equipment }\end{array}$ & $\begin{array}{l}\text { Group } \\
\text { Exercise/Personal } \\
\text { Training }\end{array}$ & $\begin{array}{l}\text { Group } \\
\text { Exercise/Equipment/Personal } \\
\text { training }\end{array}$ \\
\hline 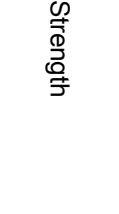 & $\begin{array}{l}\text { Large area and cc } \\
\text { Wide users }\end{array}$ & mprehensive co & erage & $\begin{array}{l}\text {-Focus on } \\
\text { service } \\
\text {-Professional } \\
\text { personal } \\
\text { trainer }\end{array}$ & $\begin{array}{l}\text {-Focus on sub- } \\
\text { segment } \\
\text {-Personalized } \\
\text { service }\end{array}$ & $\begin{array}{l}\text {-Flexible charging model } \\
\text {-Low price per } \\
\text { customer } \\
\text {-Low operating cost }\end{array}$ \\
\hline 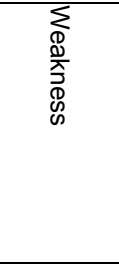 & $\begin{array}{l}\text {-High operating cc } \\
\text {-Emphasize cust } \\
\text { service and conte }\end{array}$ & st & rather $\cdot$ than & $\begin{array}{l}\text {-Little } \\
\text { equipment } \\
\text {-Fewer } \\
\text { members } \\
\text { due to area } \\
\text { limitation }\end{array}$ & $\begin{array}{l}\text {-Less supporting } \\
\text { facilities } \\
\text {-Fewer members } \\
\text { due to area } \\
\text { limitation }\end{array}$ & -Less supporting facilities \\
\hline $\begin{array}{l}\frac{w}{0} \\
\frac{0}{20} \\
\frac{0}{\omega}\end{array}$ & $\begin{array}{l}\text { Totally eight } \\
\text { brands, } \\
\text { including Will's, } \\
\text { Tera Wellness, } \\
\text { LuckyBird, } \\
\text { Good Feeling, } \\
\text { Powerhouse, } \\
\text { SINOFIT, } \\
\text { Physical and } \\
\text { WHYTEWOOLF }\end{array}$ & $\begin{array}{l}\text { INGYM, Total } \\
\text { Fitness, } \\
\text { MIRAKO } \\
\text { FITNESS, } \\
\text { The One } \\
\text { Fitness, } \\
\text { Golden } \\
\text { Times, } \\
\text { Megafit, King } \\
\text { Sport, Feel } \\
\text { Well, } \\
\text { Haoheng } \\
\text { Fitness, } \\
\text { Hyhclub, } \\
\text { World } \\
\text { Fitness, } \\
\text { KINGZONG, } \\
\text { Healthpark, } \\
\text { Zero Distance } \\
\text { Fitness, Just } \\
\text { Gyms, Black } \\
\text { Steed, Mr \& } \\
\text { Mrs Fitness, } \\
\text { Impulse, etc. }\end{array}$ & $\begin{array}{l}\text { Individual } \\
\text { brands }\end{array}$ & $\begin{array}{l}\text { Zhongtian } \\
\text { Fitness, E } \\
\text { Fit, etc. }\end{array}$ & $\begin{array}{l}\text { Pure Yoga, Fine } \\
\text { Yoga } \\
\text { SpaceCycle, } \\
\text { Inyoga, etc. }\end{array}$ & $\begin{array}{l}\text { LeFit, Super Monkey, } \\
\text { Kuaikuai, } \\
\text { Renmafitness, Liking Fit, etc. }\end{array}$ \\
\hline
\end{tabular}

\subsection{Country Analysis}

PEST Analysis is an essential tool to evaluate the new market by analyzing the political factors, economic factors, social factors and technological factors.

\subsubsection{Political factors}

Chinese government usually has restricted regulations over foreign investors compared to other countries. As the world's largest and scanty socialist country, the government sets up both formal and informal rules to control foreign capitals and business operations. Many foreign people claim that the political force is the most unsettled force to limit business opportunities. However, with the globalization and recent development of China, the country starts to lose the regulations and build a more welcome environment for international business. In 2015, China's new Foreign Investment Law cut red tape for foreign investors [3]. One of 
the major changes of the Draft Rules is that "it gives pre-established national treatment to foreign investors, putting foreign investors on the same legal footing as domestic PRC entities." By the new laws, foreign investors will now become real enterprises with foreign control, rather than merely foreign ownership.

Although the environment, with open market and supporting fitness initiatives, has been friendly to new businesses, the regulators are preparing to eliminate the "pre-paid" model, in which customers prepay for their membership fee. The government believes that this action will eliminate certain grey areas in terms of pricing but we can also predict that it will also put cash flow pressure onto fitness clubs.

\subsubsection{Economics Factors}

Over the last 10 years, China's economy experienced significant GDP growth.

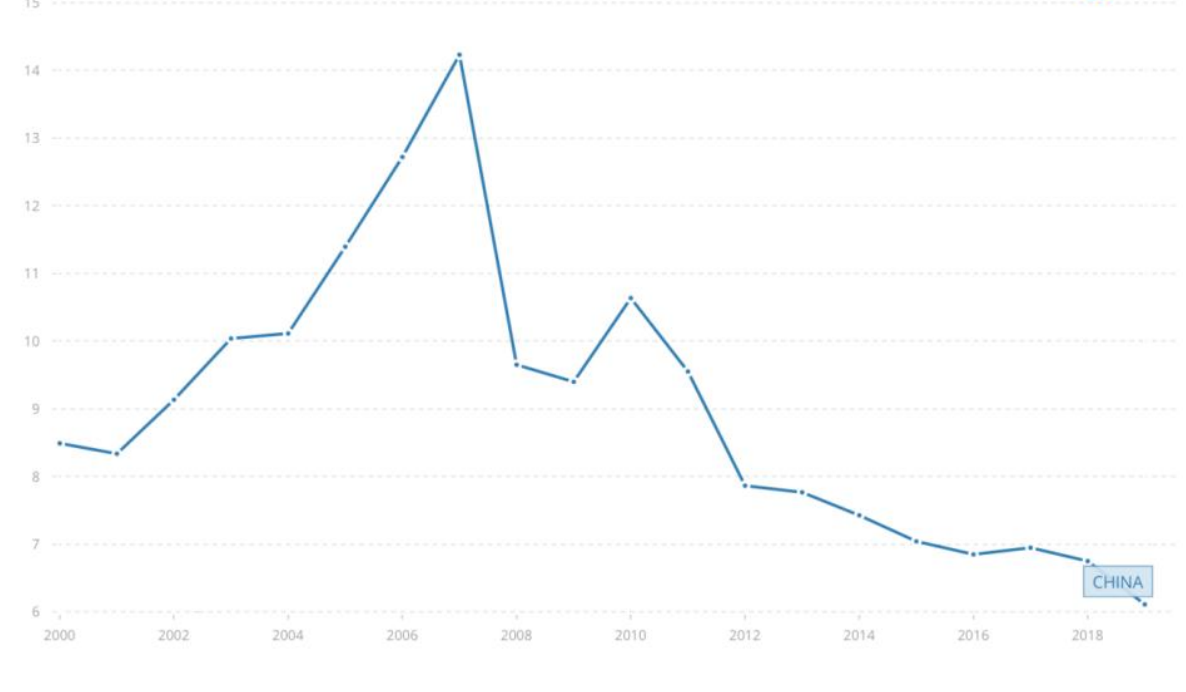

Figure 2 China’s GDP Growth (annual \%).

As the table shown above, China has an average growth rate of around 6-10 percent in the last 20 years. Even during the global recession in 2008 and 2009 , the Chinese economy still had a $6 \%$ growth rate, meaning the economy is growing strongly and stably. After 2012, China transits from High-GDP growth developing country to a more consolidated economy, as a result, the GDP keeps at a rate of a Data from World bank Website.

growth of about $6 \%$, which is still much higher than the domestic country Canada $(1 \%-2 \%)$ and our trading neighbor USA (2.5\%) [6]. The GDP growth rate suggests that the Chinese citizens add more values to the society and have increasing purchasing power. China is well known for the impressive GDP growth but also for the unbalance development of different geographic regions.

Table 3. Average Growth rate

\begin{tabular}{|l|l|l|l|l|l|}
\hline Rank & City & GDP (Billion Yuan) & Growth Rate (\%) & Population (Million) & GDP Per Capita (Yuan) \\
\hline 1 & Shanghai & 2,530 & $6.8 \%$ & 24.25 & 104,330 \\
\hline 2 & Beijing & 2,300 & $6.7 \%$ & 21.68 & 106,088 \\
\hline 3 & Guangzhou & 1,810 & $8.3 \%$ & 16.67 & 108,578 \\
\hline
\end{tabular}

However, the top three cities Shanghai, Beijing and Guangzhou with the highest GDP per capita will be the target market for the company to expand into. Besides the facts of the large population size, stable growth rate and GDP per capita, another advantage of choosing the three cities as markets is that the three cities located separated from each other. 


\subsubsection{Social Factors}

The social and cultural aspects of the country play an important role as the demographics have different values and utilities. Unlike Canada and USA, most East-Asia countries including China have not created a sturdy gym and fitness atmosphere. However, in the most recent years, the trend and lifestyle have been changed as a result of globalization. Most of the TV channels start the production of athletic-related shows, influencing the generation value more about their health, beauties and fitness performance. Behind the exercise trend is developing enthusiasm for health and fitness. As wealth accumulated, China's increasingly sophisticated middle class has the urge to disengage from work. As people's belief, fitness is now becoming a common way for them to relax and build health at the same time. However, as the trend evolve constantly and pandemic hit in 2020, consumer preference is shifting to "online + home workout" using fitness apps and group classes which are relatively cheaper and more room for interactions.

\subsubsection{Technological Factors}

The pandemic has accelerated the digitization of the fitness industry as people can only work from home during months of quarantine. Home fitness and online fitness have become familiar with more consumers and its light-asset model has far greater room to grow its user base. Traditional gyms have seen this opportunity and started to develop online live sessions and short videos. Online operation has become an inevitable trend in this industry, However, the problem now for many is how to monetize their online users.

By applying with PEST analysis, China is an attractive market in the terms of the market size, purchasing power of increased GDP per capita, and changing cultural values. The political regulation is getting better for foreign investors but still relatively restricted. According to the World Bank Group, China is ranked 84 out of 189 economies in doing business. In addition to China's protecting minority inventors (rank 134), the paying tax (rank 132) issue is another big challenge for foreign business. On top of $25 \%$ corporate income tax, there are additional social security and housing fund contributions taxes up to $30 \%$. The total tax rate of profits could be $67.2 \%$, however, the fitness and health business are more about a service industry so it can save the value-added tax (VAT) of $17 \%$ [6]. By comparing the upsides and downsides of doing business in China, we still believe that the large and growing market potential is still attractive and profitable.

\section{INDUSTRY FORECAST}

In 2014, the rate of registered members of fitness club was less than $0.5 \%$, so the maximum number of registered members was 6.5 million [6]. Moreover, the National Fitness Activities Survey illustrated that the average annual per consumption of registered member on fitness and coaching was RMB 876 [6]. The approximate value of the fitness industry was about RMB 5,694 million. In contrast, in the US, registered members of fitness clubs doubled to 33.8 million, which accounted for $13.5 \%$ of the population, from 1987 to 2001 ; in the UK, registered members of fitness clubs almost tripled to 4.4 million, accounted for $7.5 \%$ of the population, from 1996 to 2002 [6]. Conservatively, the rate of the registered member is assumed to reach $1.5 \%$ in 2020 and $2.3 \%$ in 2025. Moreover, it is assumed that the amount per consumption on fitness should grow 7\% each year, so it should reach RMB 1,845 per capita in 2025 . Therefore, the value of fitness industry would be more than RMB 61.5 billion in 2025 .

\section{SUGGESTION}

\subsection{Form of Entry}

When analyzing forms of entry, we believe that the best option for Goodlife Fitness would be to set up subsidiary company or foreign branch centering on top-tiered cities such as Beijing, Shanghai, and Shenzhen. After holding firm market shares in center cities, Goodlife Fitness could consider expanding nationwide using franchise of joint ventures. 
Table 4. Form of Entry

\begin{tabular}{|c|c|c|}
\hline & Advantages & Disadvantages \\
\hline Subsidiary & $\begin{array}{l}\text {-Separation of debt and profit/loss from parent } \\
\text { company. } \\
\text {-Has control over subsidiary. } \\
\text {-Goals and vision aligned with Goodlife Fitness. }\end{array}$ & $\begin{array}{l}\text {-Separate legal entity, although still owned by } \\
\text { Goodlife Fitness. } \\
\text {-Responsible for the success of subsidiary. Has to } \\
\text { invest in personnel, equipment and training. }\end{array}$ \\
\hline Franchise & $\begin{array}{l}\text {-Less investment in management and everyday } \\
\text { operations. } \\
\text {-Gain the franchise buy-in profit. } \\
\text {-Franchisee is more familiar with local culture and } \\
\text { habits. } \\
\text {-Can expand into more cities as fewer investments are } \\
\text { required. } \\
\text {-Enjoy the reputation of the Goodlife's brand name. }\end{array}$ & $\begin{array}{l}\text {-Doesn't have control over quality of service being } \\
\text { offered. } \\
\text {-Might potentially ruin reputation of Goodlife Fitness in } \\
\text { China. } \\
\text {-Profits do not go to Goodlife. }\end{array}$ \\
\hline Foreign Branch & $\begin{array}{l}\text {-Owned by Goodlife Fitness. } \\
\text {-Has control over operations. } \\
\text {-Equipment and services would have the same standard } \\
\text { and quality as in Canada. }\end{array}$ & $\begin{array}{l}\text {-Profit and loss tied to parent company. } \\
\text {-Invest in personnel training, management teams and } \\
\text { expatriates. }\end{array}$ \\
\hline Joint Venture & $\begin{array}{l}\text {-More capital and limited liability to losses. } \\
\text {-Local partner could have more knowledge about doing } \\
\text { business in China. } \\
\text {-Local connection network. }\end{array}$ & $\begin{array}{l}\text {-Has to share profit with partner. } \\
\text {-Might have different opinions and business } \\
\text { strategies. } \\
\text {-Potential conflict of employee distribution and } \\
\text { different contributions to the company. }\end{array}$ \\
\hline
\end{tabular}

\subsection{Marketing}

Goodlife Fitness's marketing strategy in China can take the form of sponsorships. In China, reality T.V. shows are very popular, especially with the younger generation. This group of audience is also the same people who are more likely to go gyms, since older generations tend to be more traditional and have their own forms of exercising. Moreover, Goodlife fitness could market through online social apps such as Tiktok, Wechat short film, and other media to educate the public and promote its brand. It is necessary for Goodlife Fitness to develop its own online app because users have to be directed back to Goodlife Fitness in order to monetize later. Last but not least, offline free community workshops, including square exercise, running, biking, and etc, could be held to reach end-users more directly.

\subsection{Competitive Advantages}

In the fitness industry in China, Goodlife Fitness has several advantages. First of all, it has experience and expertise. This is the most important aspect because at the core, customers care about the equipment and service provided. Many smaller gyms in China have extravagant packaging and professional marketing teams. However, their core business, which is providing an environment for people to exercise in, is much less than the industry standard. These businesses rely on deceptive marketing to lure in membership. However, once a customer registers, he/she would usually be disappointed. In this respect, Goodlife Fitness has solid company structure to succeed.

Besides membership fees, a large part of Goodlife's business comes from its trainers. People are willing to pay more for a customized workout plan that incorporates their specific goals and body conditions. It is not an exaggeration to say that Goodlife Fitness is an expert in this regard. Goodlife Fitness can bring its Goodlife Fitness Personal Training Institute to China and work with local authorities to set up a formal personal trainer standard. 
Finally, Goodlife Fitness's brand name is an advantage in itself. Being one of the largest fitness gym chains in the world, its name carries a certain weight. When Goodlife first enters China, people would not be familiar with the brand. However, anyone who is curious enough to join would naturally do a little research. Just a simple search would reveal Goodlife's leadership in the industry. Therefore, when competitor's gym has similar equipment and training provided, Goodlife Fitness's brand name would give it a competitive advantage.

\section{CONCLUSION AND RECOMMENDATION}

The primary target of Goodlife fitness in mature Canadian market as the industry bellwether is to maintain its market share and industry position. China, as the company's potential foreign market with rapid economic growth, large population and rising demand for high-quality lifestyle, is definitely a market to consider.

Via company and SWOT analysis, it is concluded that Goodlife Fitness has enough expertise and finance to succeed though there are few weaknesses in terms of globalization experience and technology development. Via Porter's five forces and PEST analysis we conclude that the Chinese fitness industry is still relatively low in penetration and has room to grow over time. However, it is also important to note that there are plenty of players already in this market, and it is important that we use our strength to its fullest and be politically right and connected.

In short term, we recommend Goodlife fitness to expand initially in first-tier cities through subsidiary or foreign branch. This approach can ensure the company has maximum control over major operations such as marketing, R\&D, HR, and finance. The primary marketing goal is to build a reputable brand image targeting young generation (40-). Goodlife Fitness can establish and experience new models such as free trainer hours, which available trainers offer 10-15 minutes free coaching slots to participants once per working time. Moreover, Goodlife Fitness should work closely with fitness government bodies to establish standard trainer qualification which trainers have to "study/test + intern/work" with Goodlife Fitness. Then, qualified trainer could have a job in Goodlife Fitness Clubs with higher retention rate and loyalty. In terms of pricing, the company should continue with the affordable membership fee and group classes. By building a stronger customer loyalty and connection, user base could grow rapidly, and we can later profit from private trainer session as well as side-line products such as sportswear and sports appliances. In terms of online application, Goodlife Fitness should definitely develop its own online platform which could provide online followalong and education courses.

In long term, we recommend that the company expand through joint ventures with local funds or players. As the company has strong brand image and trainer resource, it would attract reliable collaboration. To ensure quality and success, the company should centralize marketing, HR and IT system management. As the Chinese market is vast and diversified, it is important to collaborate with domestic conglomerate as they have resources while demands expertise.

In general, with the right strategy and partners, it would be a viable option for Goodlife Fitness to expand into the Chinese market.

\section{AUTHORS' CONTRIBUTIONS}

This paper finished by Yuan Zhai independently.

\section{ACKNOWLEDGMENTS}

This paper was supported by many parties. I would like to thank Professor Grimes for introducing the concept of "New Ventures Creation" and helping me to frame the outline of this paper. I would also like to thank my tutors for giving me advice and suggestions.

\section{REFERENCES}

[1] Jiuchang Wei, Anna Vinnikova, Liangdong $\mathrm{Lu} \&$ Jia $\mathrm{Xu}$ (2020) Understanding and Predicting the Adoption of Fitness Mobile

Apps: Evidence from China, Health Communication, DOI: 10.1080/10410236.202 0.1724637

[2] Alan MacCharles, Adrian Xu (2020). 20192020 China Health and Fitness Market White Paper, Page 5-97, https://www2.deloitte.com/content/dam/Deloit te/cn/Documents/technology-mediatelecommunications/deloitte-cn-tmt-20192020-china-gym-market-development-whitepaper-en-210115.pdf

[3] Li, Yong-Ming Ph.D.; Han, Jia Ph.D.; Liu, Yang Ph.D.; Wang, Ran Ph.D.; Wang, Ru 
Ph.D.; Wu, Xue-Ping Ph.D.; Cao, Zhen-Bo Ph.D. CHINA SURVEY OF FITNESS TRENDS FOR 2020, ACSM's Health \& Fitness Journal: 11/12 2019 - Volume 23 Issue 6 - $\mathrm{p}$ 19-27. doi: 10.1249/FIT.0000000000000522

[4] Kercher, Vanessa Ph.D., M.Ed.; Feito, Yuri Ph.D., MPH, FACSM; Yates, Brandon M.S., CSCS REGIONAL COMPARISONS: THE WORLDWIDE SURVEY OF FITNESS TRENDS, ACSM's Health \& Fitness Journal: 11/12 2019 - Volume 23 - Issue 6 - p 41-48. doi: 10.1249/FIT.0000000000000531

[5] Kercher, Vanessa M. Ph.D., SSC, M.Ed., BESS International Comparisons: ACSM's Worldwide Survey of Fitness Trends, ACSM's Health \& Fitness Journal: 11/12 2018 Volume 22 - Issue 6 - p 24-29. doi: 10.1249/FIT.0000000000000431

[6] INTERNATIONAL COMMENTARY OF THE WORLDWIDE SURVEY OF FITNESS TRENDS, ACSM's Health \& Fitness Journal: 11/12 2019 - Volume 23 - Issue 6 - p 49-51. doi: 10.1249/FIT.0000000000000527 